UDC 141.319 .8

DOI: $10.26565 / 2226-0994-2018-58-1$

Nataliia Zahurska

\title{
POST-ANTROPOCENTRIC HYPOSUBJECTIVATION
}

The article considers hyposubjectivation as the most essential kind of subjectivation in a post-Antropocentric context. Hyposubjectivation is a variety of subjectivation that takes into account the possibility and necessity of anthropological nothing or even less than nothing, the non-presence of a human being. In comparison with hyperobjects from weather catastrophes to celebrities hyposubjects appears as lacanian lamella, deleuzian double fan of a sensation or, in a more philosophicalanthropological formulation, as an uncanny ontological strange stranger. Post-Antropocentric particularization and singularization of a human being bring it to the statement of not-All as othing or hing, less than nothing. And it's a statement of hyposubject with its contingency in $n$-dimentions, agentiality, resistance to any -isms, holeness in a weird reality. In the aricle it's shown that exactly hyposubject, strange stranger realizes schizotrategies for openness of a human being, which non-presents in its meontic nothingness, or tactics of mœlting as becoming-Nature. Such an approach is developed in the aspect of non-human turn as a significant philosophical and anthropological direction. The study is based on post-postmodern philosophy, object-oriented ontology, weird, agential realism of intra-actions, etc., when a human being is considered in its manifold in nothingness. Philosophical anthropology in this case is associated with a deep, dark and weird ecology and the human being appears as a natural object devoids of its own nature. The material for the study was inured the actual cultural appearances such as the artworks of Bjork, Olafur Eliasson and A Place of a Bury Strangers, as well as relevant life practices. Thus, the principle of hyposubjectivity of a human being in a post-Antropocentric context is proved.

Keywords: post-Anthropocene, hyperobjectivation, hyposubjectivation, non-presence, fold.

The aim of this study is to consider hyposubjectivation in post-Anthropocentric, post-postmodern philosophy as an attempt to cope with spontaneity and the elementarily of human nature. In the context of weird realism, dark ecology as deep ecology is artificial in principle and at the same time aesthetically unsightly nature turns against itself and presents the same bad news. T. Morton's opinion, it is worth speaking not about Nature, which is absent in ecology, but about nature, devoid of proportional wholeness and the metaphysics of presence. "Nature, a transcendental term in a material mask, stands at the end of a potentially infinite series of other terms that collapse into it, otherwise known as a metonymic list: fish, grass, mountain air, chimpanzees, love, soda water, freedom of choice, heterosexuality, free markets... Nature. A metonymic series becomes a metaphor" [Morton, 2007, p. 14]. Dark ecology in and of itself is both a concept and a productive metaphor, referring to the notion of the presence of something that eludes the final definition, i. e. a non-presence.

This, to the same extent, applies to the human nature, and therefore the conversation about the weather as a background for human drama becomes dramatic or even tragic in itself. It increases also the degree of tragedy of the human being as such and this contains an actuality of the research. Hyperobjectivity interprets the conversation about the weather as background into a different semantic plane and brings the human to an ambiguous boundary, which is the distance between epistemological abysses or black holes, which are already here and are human and inhuman.

Hyperobjects are no longer useful for a human, but the human himself is no longer useful for himself - he fills the empty space by himself and at the same time, due to the non-obviousness of his topology, is outwardly in principal nonlocal. Therefore, the question of his situation remains open and the tasks of the research provide clarification of the possibilities for its resolution.

(c) Zahurska N. V., 2018. 
The hypersubjectivation of celebrities, which prevails over objects and does not take into account the abjection, according to degree of development of D. Boyer and T. Morton and others, remains anthropocentric. Nevertheless, stars, meteors or comets inevitably fall, fail and endure disasters; literally, dis-astron happens. Moreover, when shaking the foundations of being, something happens that can be designated as being-quake and it loses its meaningful denotation as a world. "Hyperobjects finally force us to realize the truth of the word bumiliation itself, which means being brought low, being brought down to earth" [Morton, 2013, p. 17].

In the post-Anthropocentric context the human being is like a hyperobject and the black hole of perception is bent in time, stretched between the past and the future in the relative present like a tornado or cyclone. Such a hyposubject is displaced and is not only a blurred relative to itself, but is also different from itself. Dissolution and vibration is best observed by drawing on the example of the smallest objects, the existence of which is particularly problematic. In addition, although T. Morton mentions primarily amplitudinous natural phenomena, his conception of hyperobjects is quite applicable to molecular and even atomic hyperobjects. "Like their hyperobjective environment, hyposubjects are also multiphasic and plural: not-yet, neither here nor there, less than the sum of their parts. They are, in other words, subscendent rather than transcendent. They do not pursue or pretend to absolute knowledge or language, let alone power. Instead they play; they care; they adapt; they hurt; they laugh $<\ldots>$ if we wish to thrive, it is as hyposubjects that we will become human (again)" [Boyer \& Morton, 2016].

The non-presence or non-existence of a human being as a hyposubject is his real being, not absolute oukontic nothing, but meontic nothing, which "restores not full presence but spectral intimacy to the thing" [Morton, 2013, p. 193]. Such as every object is a hyperobject, every subject is a hyposubject and just as nature is non-present in ecology, a person is non-present in anthropology. A hyposubject proves an uncanny ontological strange stranger, who always unexpectedly arrives as human and non-human simultaneously. A human being as a strange stranger is always a hypocrite too and its hypocrisy results from the conditions of the impossibility of a metalanguage, as J. Lacan notes. And this kind of approach contains the novelty of this study.

"The mirror itself has become part of my flesh. Or rather, I have become part of the mirror's flesh, reflecting hyperobjects everywhere" [Morton, 2013, p. 27] T. Morton claims on the ground that objects in the mirror are closer than they appear in the states colonizing a humanness by hyperobject, although losing a distance. A hyposubject, supposing that it observes hyperobjects from the outside, can be found inside them, including inside itself without realizing this because hyperobjects are more substantial than their effects, although their existence is unprovable. In this sense, it's viscous like a lacanian lamella, but unlike it, overrules postmodern ironic distance to post-postmodern innocence. Moreover, hyperobjects acquire a greater degree of viscosity than the greater amount of resistance they encounter.

If $G$. Harman affirms that an object is always more than its relations, then T. Morton accents interobjectivity, so far as hyperobjects are formed by relations between more than one objector within objects and presents lacanian not-all set. Each of them are not just collections or assemblages of other objects, but an object itself that has a separate life form and is a collection of things that is not this life form. This refers more to a human being as a hyposubject, whose causal dimension is insomuch relative that even sensory experience does not mark a reality, but ontically re-mark it. In the deconstructive context, a re-mark represents a blind spot or a smudge, and an inscribable surface of flat ontic and even ontological, blurring differance between a cause and a sign. From the point of view of speculative etymology, such a re-mark sorts with a mesh and, further "happily, mesh has etymological associations both with mass and with mask: that is, the heft of a thing, and its illusory qualities (qualities that, as I argue briefly here, have a causal reach)" [Morton, 2013, p. 83].

Viscosity is a sort of molting and, thus, living and immortal hyperobjects deconstruct space-time fixing, viscerally absorbing not only things, but also words, as T. Morton notes in his correspondence with Björk in This huge sunlit abyss from the future right there next to you. Applying 
T. Morton's concept, it can be argued that this is the correspondence between non-human hyperobjects, elements, while the hyperobjects are very stylistically sophisticated and sensual up to molten ether. Björk dwells in search of -ism, which at the same time best describes her as a creator, creation and creature (given her obviously naturalistic intentions). She does not stop on easternism (only pain is not suffering), spinosism (thinking should know to laugh and cry), posthumanism, mysterious realism or paneroticism and, with T. Morton's influence, who accented the dynamic of the whole reality and that game is a wisdom rather than a love to a wisdom: "there is an essence, and it's right here, in the object resplendent with its sensual qualities yet withdrawn" [Morton, 2013, p. 159].

Finally, Björk appeares outside any ism:

"so even classical shit or world music or whatever genre

was like erased if it didn't swing ... and the further reach the better :

ARTIST

like drones, buildings or them Buddhist things ? looped and gridded

GAPS

streamlined and abstract swirling Sufi style all around you

PHILOSOPHER'S

we must unite the two , tim

MIND" [Björk, 2015, p. 21].

Björk acts in a shamanic manner and contributes to the north witchy-bitchy shamanism as post-postmodern. "Art and life need not be mutually exclusive. <...> So go ahead and unleash your inner post-postmodern Icelandic Shaman, but for everyone's sake, don't be a literalist about it" [Braithwaite, 2010]. Despite this, she is an author of multitude artifacts and appears as an artifact or hyperobject herself.

The same can be said about Olafur Eliasson and other artists, who set the post-postmodern context and with whom T. Morton actively collaborates. Just from Björk's creation T. Morton adopted the conception of non-human perception $n$-dimensional non-local entities and phasing. Nevertheless, if all phasing objects are always not-all, hyperobjects are always merging objects themselves. Thus, Björk appears not as a literalist, but as an agent in $\mathrm{K}$. Barad's interpretation. K. Barad insists that agential is a matter or intra-action or enactment, but not possession. Enactment emphasizes that agential matter is not passive material, but causes surface effects. Thus, agential realism potentially includes not only human, but also nonhuman, both living and nonliving, cyborgian or natural: a "posthumanist refiguration of the nature of materiality and discursivity and the relationship between them" [Barad, 2003, p. 818]. If D. Haraway epitomizes (de)stabilization of differential boundaries, then $\mathrm{K}$. Barad ontologizes it and considers the phenomena as dynamic relationality, mutuality through specific causal and non-causal, klinamenal intra-actions. Agential realism may be combined with real realism, applying M. Hansen's concept, who draws attention to the fact that preemptive power "mobilizes the affect of fear to effectively trigger a virtual causality" [Hansen, 2015, p. 105]. He combined real realism with non-relational object-oriented ontology in the perception of G. Harman. Such an approach gives the possibility to start rethinking relations of objects repeatedly. Thus, objects as agents, entities in their intra-actions realize inaccessible withdrawal as possibility of real realism or ontology without the privilege hierarchy of entities.

When L. Morelle raises the issue on the reality of speculative realism itself, which already undoubtedly really exists, he suggests paying attention to the fact that "yet correlationism only consists in elevating a specific type of relation above all others - the relation between human being and world. In order to maintain a reality full of individual objects, it is necessary to assert that there is no ontological difference between subject/object relations and object/object relations" [Morelle, 2012, p. 252]. Both subjects and objects in this case act as agents with high sentience, because of their inclination to particularizing.

Proceeding from paradoxical sorting of J. Deleuze's and F. Shelling's conceptions, I. H. Grant asserts that dark onthology particularizing will realize the chemistry of darkness 
not on the surface, but in the depths. Just in such particularization a contingency appears: "on the basis of the unground, and through the medium of the word that introduces the break between the forces that affect us, the quality and intensity of the matter thus affected, and the affecting of us, such that there is a continuity coursing through the sealed particularity of mind» [Grant, 2000, p. 50].

G. Deleuze suggests the metaphor of a fan, which is inseparable from the wind, for particularization and sigularization. As T. Conley notes, "an event unfolds from the union of our perception and the duration of a fan $<\ldots>$ that unites and disperses a word (an event) and an object (an eventail) when it swirls the atmosphere" [Deleuze, 2006, p. xiii]. Folds may be interpreted as phases, particles of matter, dust, ashes, fog or mist, stirring up inanity, disquiet, swarming holes, hollow collectivities, armies and hallucinating assemblies, which are organized in multiple leaves in monad books: "it contains every fold, since the combinations of its pages are infinite, but it includes them in its closure, and all its actions are internal" [Deleuze, 2006, p. 34]. The metaphor of a fan, even a double fan can also be implied to corporeality, such as in El Greco's: "the counter-fold of the calf and knee. The knee as an inversion of the calf confers on the leg an infinite undulation, while the seam of the cloud in the middle transforms it into a double fan..." [Deleuze, 2006, p. 38-39]. It demonstrates at once both types of the folds, which severe and cast each other. The open or disseminate one is supported by a cloud and the close one is supported by granite or marble with vein lets and which, according to G. Leibnitz, is densely compacted in thick layerings of scepter. Their combination occurs through the double fan, especially the double fan of a book, so dynamically expanding the voids that it is impossible to see, but possible to read.

These considerations of J. Deleuze were suggested not only by G. Leibnitz and S. Mallarme, but primarily by W. Benjamin who presupposes an availability of "inventing, for every intensity, an extensiveness to contain its new, compressed fullness, in short, of receiving each image as if it were that of the folded fan, which only in spreading draws breath and flourished, in its new expanse, the beloved features within it" [Benjamin, 1979, p. 75]. That is why the fold always has two sides - the pulling and the tension between which it is itself.

S. Žižek affirms that " 'moving' is the striving to reach the void, namely, 'things move', there is something instead of nothing, not because reality is in excess in comparison with mere nothing, but because reality is less than notbing" [Žižek, 2012, p. 4]. He draws attention to a certain dissonance within this statement itself, the coincidence of the subject of lack and the subject of excess, more precisely, the transition of the subject of excess to the subject of lack. This means that in order to become nothing, there must already be something, or even many, all too many; human, all too human. Lacan's formula of sexuality is the following: All with the exception, not-All, he also suggests understanding as less than One, but more than nothing, y'a de den. Moving is carried out in the direction "from the ontological principle of non-contradiction to the principle that there is no sexual relationship" [Žižek, 2012, p. 797]. The aphoristical lacanian formulation is the following:

- Notbing, perhaps?

- Not perbaps notbing, but not notbing.

According to M. Dolar means, that "atomistic one is the one of a split, a split one, the one as introducing a split, a crack into being, the one that cannot totalize being under the heading of one, but splits it into infinity and makes it non-totalizable" [Dolar, 2013, p. 13]. In order to denote this kind of disjunction between thing and nothing, W. I. Matson suggests using bing, while M. Dolar proposes othing.

S. Žižek assumes that substances are mentioned of nothing themselves, and in this connection the very concept of the object is inverted and turned inside out. It becomes possible due to the fact that, in this case, othing means the pure difference between two nothings. Just like I. H. Grant, S. Žižek draws attention to the fact that the break in the very foundation is already introduced by F. Schelling, and this position entirely implements the nonabsolute empiricism of G. Deleuze. "Diffraction itself is thus diffracted into combining and splitting, into overlapping 
and spreading" [Žižek, 2012, p. 949]. He notes that because hings are not symmetrical, One always retards with regard to itself and that is why nothing always reveals itself as "false", but not only illusive, while implementing minimal incessant activity and disturbance is drawn as "true" and traumatic disturbance, providing balance maintenance. It corresponds with pursuit to the truth and trust, which post-postmodern eventuality possesses.

For M. Dolar pure surplus of the split is not negation or exorcizing of negation, but subtraction or removal of negation: "this is the mindboggling speculative turn - a subtraction from non-being, as negativity effacing itself" [Dolar, 2013, p. 23]. And othing is detected in the gap between neither the nothing and the proliferative multiplicity. Othing as an object in its best way is demonstrated in objectum-sexuality, which means treating a partner as an object. But it is not an object for masturbation, because "in objectum-sexuality one has sex with the object because one loves the object itself" [Clemens \& Pettman, 2004, p. 40]. In this case, an object, including a natural one, such as a pet, for example, a carrollian rabbit, is alive, where as a subject is avoided as J. Clemens and D. Pettman note. This is an attempt to solve the problematical character of the subject-subject relations marked by S. Zižek. It is the treatment of a partner as an object, othing, which is not handy, because its noumenality is brought to the forefront. This enables one and one's partner to avoid excessive subjectification and use it entirely without partitioning a lot of fetishes. At the same time, a high degree of noumenal freedom makes it possible, through interaction with one object, to interact with a lot of objects at once, because "when you approach an object, more and more objects emerge" [Morton, 2013, p. 55] in a multi-folding of time and space.

Thus, hyposubject appears as strange stranger, which through a dissemination of a distance makes its othingness feel acutely real. In this case, avoided subject is proved buried in the fold of its subjectivation and simultaneously is carried away as a cyclone, like in "We've Come So Far" by A Place of a Bury Strangers:

Tastes so real, I lost myself into there

Feels so real, I lost myself into there

I feel right now we've come so far

I feel right now we've come so far

Far, far, far, far, far, far, far, far.

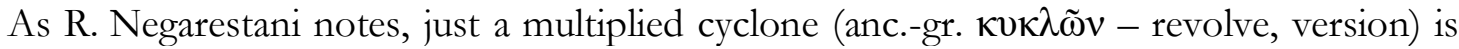
the best phrasing of the relativity of distance. One of Björk's early projects was named kuklon from Kukl (islandic Sorcery or Witchcraft), but in this case, it means rather byperstition (portmanteau of hyper and superstition - active changing of reality in its $n$-dimensions. In the center of a cyclone complex, implying both a destitute Whole and a holey-ness, which "speeds up and triggers a particular subversion in solid bodies such as the earth. It unfolds holes as ambiguous entities oscillating between surface and depth" [Negarestani, 2008, p. 43]. Such an ungrounding is combined with J. Deleuze and F. Guattari's white wall/black hole and dusting a face into molecules in the process of shizo's katabasis. This implements polytics as politics of becoming and extensions of eventual schizotrategies for openness: "the polytics of the Oholey complex defies existing models of the harvesting of power correlated to the logic of the ground and the politics of whole" [Negarestani, 2008, p. 53].

Schizotrategies are not always open (to), but when opened (by) multiple entities, repel outsiders and xeno-agents. Over-killed and exhumed humans become a xerodrome of cremation-to-Dust or becoming-Gas. In R. Negarestanis words "furious resistance is exponentially intensified and progressively overrun by xeno-agents until meltdown, the becoming-GAS of all particles" [Negarestani, 2008, p. 119]. Simultaneously, crisp boundary of poly-surfaced tissues is blurred and dissolved through dark matter, such as the mist mare of petrol as Tellurian Lube.

Thus, in conclusion, it is worth noting that hyposubjectivation, in comparison to hypersubjectivation, is becoming-Nature, mœlting (molting and melting) as a tactic of post-Anthropocentric hyposubjectivation. Post-Anthropocentric human begins as a hole, 
a nothing, a hing or an othing and this lets it realize agency and intra-action in a weird reality. The hypersubjectivation reflects the tendency to change priorities from domination to strange strangeness in a dark matter. The position of non-presence is fundamentally unstable and fits to human beings with its openness. The hyposubjectivation makes it possible to create a multi-folding environment of post-Anthropocene.

\section{REFERENCES}

Barad, K. (2003). Posthumanist Performativity: Toward an Understanding of How Matter Comes to Matter. Signs, Spring, 801-831.

Braithwaite, M. (2010). Post-Postmodern Icelandic Shamanism. Retrieved from https://ironingboardcollective.wordpress.com/2010/06/08/post-postmodern-icelandicshamanism-boho-new-age-need-not-apply.

Benjamin, W. (1979). One Way Street And Other Writings. London: NLB.

Björk, (2015). This huge sunlit abyss from the future right there next to you ... : emails between Björk Guðmundsdóttir and Timothy Morton. In Björk, Archives (Vol. IV). London: Thames and Hudson.

Boyer, D., \& Morton, T. (2016, January). Hyposubject. Cultural Anthropology, 21. Retrieved from https://culanth.org/fieldsights/798-hyposubjects.

Clemens, J., \& Pettman, D. (2004). Avoiding the Subject. Media, Culture and the Object. Amsterdam: Amsterdam University Press.

Deleuze, G. (2006). The Fold: Leibniz and the Baroque. (T. Conley, Trans.). London: Continuum. (Original work published 1988).

Dolar, M. (2013). The Atom and the Void - from Democritus to Lacan. Filozofski vestnik, XXXIV(2), 11-26.

Grant, I. H. (2000). The Chemistry of Darkness. Pli, 9, 36-52.

Hansen, M. (2015). Our Predictive Condition; or, Prediction in the Wild. In R. Grusin (Ed.), The Nonbuman Turn (pp. 101-138). Minesotta: Minesotta UP.

Morelle, L. (2012). Speculative Realism. After finitude, and beyond? A vade mecum. Speculations, III, 241-272.

Morton, T. (2007). Ecology Without Nature: Rethinking Environmental Aesthetics. Cambridge, MA and London: University Press.

Morton, T. (2013). Hyperobjects: Philosophy and Ecology after the End of the World. Minneapolis: University of Minnesota Press.

Negarestani, R. (2008). Cyclonopedia: Complicity with Anonymous Materials. Melbourn: re.press.

Žižek, S. (2012). Less than nothing: Hegel and the shadow of dialectical materialism. London: Verso.

\section{Zahurska Nataliia V.}

D.Sc. in Philosophy, Professor of the Department of Theoretical and Practical Philosophy named after Professor J. B. Schad

V. N. Karazin Kharkiv National University

6, Svobody sqr., 61022, Kharkiv, Ukraine

E-mail: zagurskaya@karazin.ua

ORCID: http:/ /orcid.org/0000-0001-5142-8064

Article arrived: 12.04 .2018

Accepted: 14.05 .2018

\section{ПОСТ-АНТРОПОЦЕННА ГІПОСУБ'ЄКТИВАЦІЯ}

\section{Загурська Наталія Віталіївна}

Аоктор філософських наук, професор кафелри теоретичної і практичної філософії імені професора Й. Б. ШаАа

Харківський національний університет імені В. Н. Каразіна

м. Свободи, 6, Харків, 61022

E-mail: zagurskaya@karazin.ua

ORCID: http:/ /orcid.org/0000-0001-5142-8064 
У статті розгляАається гіпосуб์'єктивація як найбільш суттевий виА суб’ективації у пост-Антропоценному контексті. Гіпосуб’єктивація становить різновиА суб̊єєкивації, яка враховує можливість і необхіАність антропологічного ніщо або навіть меншого, ніж ніщо, - не-присутності АюАської істоти. Порівняно з гіпероб’єктами (віА погодних катастроф до селебрітіз), гіпосуб'єкти постають Ааканіанською «Аамелою», Аельозіанським «подвійним віялом сенсації» як продуктивними метафорами або, у більш філософсько-антропологічному формулюванні, моторошним онтологічним «Аивним Аиваком». Пост-антропоценна партикулярізація та сингулярізація Аюдської істоти вводить іï у стан не-Всього як іщо, ечі, меньшого, ніж ніщо. I це стан гіросуб’єкта з його контингентністю у n-вимірах, агентурністю, спротиву будь-яким -ізмам, пустотності в Аивній реальності. У статті показано, що саме гіпосуб'єкт, «Аивний дивак» реалізує шизотратегії заради

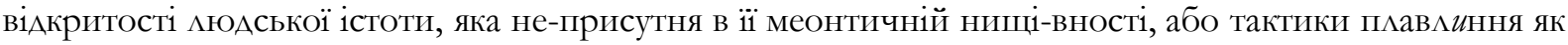
становлення-Природою. Такий піАхіА розвивається в аспекті не-АюАського повороту як значущого філософсько-антропологічного напряму. АосліАження грунтується на філософії пост-постмодерна, об’ект-орієнтованої онтології, Аивному, агентурному реалізмі інтра-акцій тощо, де АюАська істота розглядається в багатоманітті іiі нищі-вності. Філософська антропологія в цьому випадку змикається з глибинною, темною та Аивною екологією, а АюАська істота постає природним об'єктом, що є позбавленим власної природи. Матеріал Аля досліАження становили актуальні культурні явища, як-от творчість Бйорк, Олафура Еліассона та «A Place of a Bury Strangers», а також віАповіАні життєві практики в подієвості постпостмодерна. Таким чином стверджується принцип гіпосуб์’єкивації Аюдської істоти в пост-Антропоценному контексті.

Ключові смова: пост-Антропоцен, гіпероб์єктивація, гіпосуб’'єктивація, не-присутність, складка.

Стаття надійшла до редакції: 12.04.2018

Схвалено Ао Аруку: 14.05.2018

\section{ПОСТ-АНТРОПОЦЕННАЯ ГИПОСУБЪЕКТИВАЦИЯ}

\section{Загурская Наталья Витамьевна}

Аоктор философских наук, профессор кафедры теоретической и практической философии имени профессора И. Б. ШаАа

Харьковський национальный университет имени В. Н. Каразина

пл. Свободы, 6, Харьков, 61022

E-mail: zagurskaya@karazin.ua

ORCID: http://orcid.org/0000-0001-5142-8064

В статье рассматривается гипосубъективация как наиболее существенный виА субъъктивации в пост-Антропоценном контексте. Гипосубъективацией явАяется разновиАность субъективации, которая учитывает возможность и необходимость антропологического ничто или Ааже меньшего, чем ничто, - не-присутствия человеческого существа. По сравнению с гиперобъектами (от погодных катастроф до селебритиз), гипосубъъекты предстают Ааканианской «ламелмой», Аелезианским «Авойным веером сенсации» или, в более философскоантропологической формулировке, жутким онтологическим «странным странником». Пост-Антропоценная партикуляризация и сингуляризация человеческого существа приводит его в состояние не-Всего как ичто, ещи, меньшего, чем ничто. И это состояние гипосуб̆ъекта с его контингентностью в $n$-измерениях, агентурностью, противостоянием кюбого рода -измам, пустотности в странной реальности. Именно гипосубъъект, «странный странник» реализует шизотратегии ради открытости человеческого существа, которое не-присутствует в его меонтической ничто-жности, или тактики плавАиния как становления-Природой. Такой подхоА развивается в аспекте не-человеческого поворота как значимого философско-антропологического направления. Исследование основано на философии пост-постмодерна, объект-ориентированной онтологии, странном, агентурном реализме интра-акций и т.А., гАе человеческое существо рассматривается в многообразии его ничто-жности. Философская антропология в этом случае смыкается с глубинной, тёмной и странной экологией, а человеческое существо преАстаёт природным объектом, Аишённым собственной природы.

Ключевые смова: пост-Антропоцен, гиперобъективация, гипосубъективация, не-присутствие, складка. 